\title{
Kemitraan Pemerintah-Swasta dalam Industri Pangan untuk Menurunkan Kandungan Gula, Garam dan Lemak dalam Pangan Olahan
}

\author{
Asep Kusnali ${ }^{1}$, Herti Windya Puspasari ${ }^{2}$, Rustika ${ }^{3}$ \\ Puslitbang Humaniora dan Manajemen Kesehatan, Badan Litbangkes, Kemenkes RI \\ J1. Percetakan Negara No.29, Johar Baru, Kota Jakarta Pusat, Daerah Khusus Ibukota Jakarta 10560 \\ asepkusnali@yahoo.com ${ }^{1}, \underline{\text { herti_windya_p@yahoo.com }}{ }^{2}, \underline{\text { rustikaherman@yahoo.co.id }{ }^{3}}$
}

\begin{abstract}
Abstrak
Pemerintah menetapkan Permenkes No. 30 Tahun 2013 tentang Pencantuman Informasi Kandungan Gula, Garam dan Lemak serta Pesan Kesehatan untuk Pangan Olahan dan Pangan Siap Saji untuk melindungi masyarakat dari risiko penyakit tidak menular yang disebabkan oleh asupan, gula, garam dan lemak berlebih. Petunjuk teknis yang mencantumkan jenis pangan olahan, cara pengujian dan zat gizi belum diterbitkan sehingga kebijakan ini belum dapat diimplementasikan oleh industri pangan. Tujuan kajian adalah menganalisis bentuk kemitraan pemerintah-swasta dalam pelaksanaan kebijakan pencantuman informasi kandungan gula, garam dan lemak serta pesan kesehatan untuk pangan olahan. Kajian merupakan jenis normatif empiris dengan analisis menggunkan pendekatan kualitatif. Data primer di kumpulkan melalui teknik wawancara dan round table discussion sedangkan data sekunder melalui bahan pustaka dan regulasi. Hasil kajian menunjukkan kemitraan pemerintah-swasta dengan industri pangan merupakan langkah strategis dalam mendukung program menurunkan prevalensi penyakit tidak menular yang diakibatkan konsumsi gula, garam dan lemak berlebih. Industri pangan telah menawarkan langkah kerjasama dengan Pemerintah untuk menurunkan kandungan gula, garam dan lemak dalam pangan olahan seperti Public Health Responsibility Deal dan Millan Declaration. Kemitraan PemerintahSwasta juga merupakan alternatif kebijakan yang dapat mendorong peran aktif dari industri pangan untuk memproduksi pangan yang lebih sehat.
\end{abstract}

Kata kunci: industri pangan, kemitraan pemerintah-swasta, pangan olahan

\begin{abstract}
The Government has has made a Regulation of the Health Minister No. 30 of 2013 about The Inclusion of information on Sugar, Salt and Fat Contents as well as Health Messages on Processed Foods and Fast Food to protect the public from the risk of non-communicable diseases caused by excessive intake, sugar, salt and fat. However, the policy caused concern for the food industry because it could restrict trade. Technical instructions that include types of processed food, methods of testing and nutrients have not been published so that this policy cannot be implemented by the food industry. For this reason. The purpose of the study is to analyze the form of public-private partnerships in the implementation of the policy of including information on the content of sugar, salt and fat and health messages for processed food. The study is an empirical normative type with analysis using a qualitative approach. Primary data is collected through interview techniques and round table discussions while secondary data is through library materials and regulations. The results of the study show that public-private partnerships with the food industry are a strategic step in supporting the program to reduce the prevalence of noncommunicable diseases caused by consumption of sugar, salt and excess fat. The food industry offers a step in cooperation with the Government to reduce the sugar, salt and fat content in processed food such as Public Health Responsibility Deal and Millan Declaration. Public-Private Partnerships are also policy alternatives that can encourage the active role of the food industry to produce healthier food.
\end{abstract}

Keywords : food industry, public-provate partnership, processed food 


\section{Pendahuluan}

Gambaran pola penyakit penyebab utama kematian di Indonesia telah menunjukkan adanya transisi epidemiologi yang diikuti dengan transisi demografi dan teknologi, yakni perubahan pola penyakit dari penyakit menular menjadi penyakit tidak menular yang kemudian menjadi faktor utama penyebab morbiditas dan mortalitas ${ }^{1}$. Pola perilaku konsumsi makanan mengandung gula, garam dan lemak berlebih merupakan salah satu pemicu semakin banyaknya penyakit tidak menular yang banyak terjadi di usia muda ${ }^{2}$.

Data WHO (2014) dalam NCD Country Profiles 2014 menyebutkan sekitar 71\% kematian di Indonesia disebabkan oleh penyakit tidak menular, yang meliputi diabetes sekitar $6 \%$, penyakit pernapasan kronik sekitar 5\%, kanker sekitar 13\%, penyakit tidak menular lainnya sekitar $10 \%$ dan paling banyak kematian disebabkan penyakit kardiovaskular dengan proporsi sekitar $37 \%^{3}$. Demikian pula dalam data Riset Kesehatan Dasar (2013) menunjukkan perilaku konsumsi makanan berisiko pada penduduk umur $\geq 10$ tahun paling banyak adalah konsumsi bumbu penyedap (77,3\%), diikuti makanan dan minuman manis $(53,1 \%)$, dan makanan berlemak $(40,7 \%)$. Hal ini menyebabkan peningkatan prevalensi hipertensi dari 7,6\% tahun 2007 menjadi 9,5\% pada tahun 2013. Hal yang sama untuk stroke juga meningkat dari 8,3 per1000 pada tahun 2007 menjadi 12,1 per1000 di tahun 2013. Begitu pula diabetes terjadi peningkatan dari $1,1 \%$ menjadi $2,1 \%{ }^{4}$.

Tingginya prevalensi penyakit tidak menular telah berdampak pada meningkatnya biaya kesehatan dan pertumbuhan beban penyakit ${ }^{5}$. Sehingga beban ekonomi akibat penyakit tidak menular ini harus menjadi perhatian dari pelaksanaan Jaminan Kesehatan Nasional (JKN). Salah satu upaya Pemerintah dalam melindungi kesehatan masyarakat adalah melakukan edukasi kepada masyarakat melalui informasi kandungan gula, garam, dan lemak, serta pesan kesehatan yang dicantumkan dalam kemasan pangan olahan. Upaya tersebut diperkuat dengan diterbitkannya Permenkes No. 30 Tahun 2013 tentang Pencantuman Informasi Kandungan Gula, Garam dan Lemak serta Pesan Kesehatan untuk Pangan Olahan dan Pangan Siap Saji. Kebijakan tersebut mewajibkan industri pangan olahan untuk menginformasikan kandungan total dari gula, garam, dan lemak, serta pesan kesehatan pada label pangan olahan yang berbunyi "Konsumsi Gula lebih dari 50 gram, Natrium lebih dari 2000 miligram, atau Lemak total lebih dari 67 gram per orang per hari berisiko hipertensi, stroke, diabetes, dan serangan jantung"6.

Implementasi Permenkes No. 30 Tahun 2013 perlu melibatkan peran dan kontribusi lintas sektor dan dunia usaha. Namun, berlakunya kebijakan tersebut dianggap menjadi hambatan bagi industri pangan olahan baik nasional maupun internasional karena kebijakan tersebut merupakan regulasi teknis yang memberlakukan suatu standar dan prosedur dalam pangan olahan untuk diperdagangkan (Badan Standardisasi Nasional, 2014) ${ }^{7}$. Dengan mempertimbangkan kesiapan pihak industri pangan dan regulasi teknis yang masih disusun, Permenkes No. 30 Tahun 2013 ditunda sampai dengan tahun 2019 
Asep Kusnali, Herti Windya Puspasari, Rustika. Kemitraan Pemerintah-Swasta dalam Industri Pangan untuk Menurunkan Kandungan Gula, Garam dan Lemak dalam Pangan Olahan. DOI:

yang ditetapkan melalui Permenkes No. 63 Tahun 2015 tentang Perubahan atas Peraturan Menteri Kesehatan Nomor 30 Tahun 2013 tentang Pencantuman Informasi Kandungan Gula, Garam dan Lemak serta Pesan Kesehatan untuk Pangan Olahan dan Pangan Siap Saji ${ }^{8}$.

Kajian ini bertujuan untuk menganalisis kemitraan pemerintah-swasta dengan industri pangan olahan di Indonesia dalam melaksanakan Permenkes No. 30 Tahun 2013 tentang Pencantuman Informasi Kandungan Gula, Garam dan Lemak serta Pesan Kesehatan untuk Pangan Olahan dan Pangan Siap Saji.

\section{Metode}

Kajian ini merupakan kajian empiris terhadap hukum dan kebijakan dalam Permenkes No. 30 Tahun 2013. Kajian dilaksanakan di DKI Jakarta mulai September sampai dengan Nopember 2017 dengan metode pengumpulan data primer melalui wawancara mendalam dan Round Table Discussion terhadap pemangku kepentingan di Kementerian Kesehatan RI, Badan Pengawas Obat dan Makanan (BPOM), dan Gabungan Pengusaha Makanan dan Minuman Indonesia (GAPMMI), sedangkan data sekunder berupa peraturan perundang-undangan, hasil-hasil penelitian sebelumnya dan bahan lain yang relevan dengan tujuan kajian. Data diambil dari hasil kajian pada Pusat Penelitian dan Pengembangan Humaniora dan Manajemen Kesehatan dengan judul "Kajian terhadap Kebijakan Pencantuman Informasi Kandungan Gula, Garam dan Lemak serta Pesan Kesehatan untuk Pangan Olahan dan Pangan Siap Saji" pada tahun 2017. Data dianalisis melalui pendekatan kualitatif yang menginterpretasikan data hasil kajian dan berfokus pada fenomena sosial.

\section{Hasil}

Tabel 1. Perbedaan keterangan label berdasarkan Peraturan Pelabelan di Indonesia, Eropa, Amerika Serikat, Australia dan Global

\begin{tabular}{|c|c|c|c|c|c|}
\hline Keterangan minimal label & $\begin{array}{l}\text { PP No. } \\
\text { 69/1999 } \\
\text { (Indonesia) }\end{array}$ & $\begin{array}{l}\text { EC } \\
2000 / 13 \\
\text { (Eropa) }\end{array}$ & $\begin{array}{l}\text { Food } \\
\text { Labelling } \\
\text { Guide } \\
\text { (Amerika } \\
\text { Serikat) }\end{array}$ & $\begin{array}{l}\text { Australian } \\
\text { Labelling of } \\
\text { Packaged } \\
\text { Food } \\
\text { (Australia) }\end{array}$ & $\begin{array}{l}\text { Codex Stan } \\
\text { 1-1985 } \\
\text { (Rujukan } \\
\text { seluruh } \\
\text { Negara) }\end{array}$ \\
\hline Nama produk & $\sqrt{ }$ & $\sqrt{ }$ & $\sqrt{ }$ & $\sqrt{ }$ & $\sqrt{ }$ \\
\hline Berat bersih / netto & $\sqrt{ }$ & $\sqrt{ }$ & $\sqrt{ }$ & $\sqrt{ }$ & $\sqrt{ }$ \\
\hline Nama \& alamat produsen & $\sqrt{ }$ & $\sqrt{ }$ & $\sqrt{ }$ & $\sqrt{ }$ & $\sqrt{ }$ \\
\hline Daftar bahan & $\sqrt{ }$ & $\sqrt{ }$ & $\sqrt{ }$ & $\sqrt{ }$ & $\sqrt{ }$ \\
\hline Tanggal kadaluwarsa & $\sqrt{ }$ & $\sqrt{ }$ & - & $\sqrt{ }$ & $\sqrt{ }$ \\
\hline Informasi gizi & - & - & $\sqrt{ }$ & $\sqrt{ }$ & - \\
\hline Kode produksi & - & - & - & $\sqrt{ }$ & $\sqrt{ }$ \\
\hline Asal produk & - & $\sqrt{ }$ & - & - & $\sqrt{ }$ \\
\hline Informasi allergen & - & - & - & $\sqrt{ }$ & - \\
\hline Cara penyimpanan & - & $\sqrt{ }$ & - & $\sqrt{ }$ & $\sqrt{ }$ \\
\hline Petunjuk penggunaan & - & $\sqrt{ }$ & - & $\sqrt{ }$ & $\sqrt{ }$ \\
\hline Jumlah diatur & 5 & 8 & 5 & 10 & 9 \\
\hline
\end{tabular}

Keterangan: $\sqrt{ }=$ diatur, - = tidak diatur 
Selain beberapa ketentuan wajib yang perlu dicantumkan dalam label pangan di atas, beberapa informasi tambahan yang dapat dicantumkan dan tidak bersifat wajib adalah energi dari lemak jenuh, lemak tidak jenuh tunggal, lemak tidak jenuh ganda, kalium, serat pangan larut, serat pangan tidak larut, gula alkohol, karbohidrat lain, vitamin dan zat gizi lain (Tabel 2).

Tabel 2. Kewajiban yang Harus Dicantumkan dalam Label Pangan Berdasarkan PerKa BPOM No. HK.00.06.51.0475 tentang Pedoman Pencantuman Informasi Nilai Gizi pada Label Pangan

\begin{tabular}{l}
\hline $\begin{array}{c}\text { Informasi yang Wajib } \\
\text { dicantumkan }\end{array}$ \\
\hline 1. Takaran saji: BPOM \\
berwenang menyetujui takaran \\
saji daat penilaian kemanan \\
pangan atau pendaftaran \\
dicantumkan dalam satuan \\
metrik seperti mg, g, ml \\
2. Jumlah Sajian per Kemasan: \\
jumlah takaran saji yang \\
terdapat dalam satu kemasan \\
pangan
\end{tabular}

3. Catatan Kaki: persentase AKG yang ditunjukkan dalam informasi nilia gizi dihitung berdasarkan kebutuhan energi 2000 kkal. Tidak wajib bagi pangan yang ditujukan anak usia 6-24 bulan dan anak usia 2-5 tahun.

\section{Zat Gizi yang Wajib Dicantumkan}

1. Energi Total: berasal dari lemak, protein dan karbohidrat dalam satuan kkal per takaran saji

2. Lemak Total: kandungan semua asam lemak dalam pangan yang dinyatakan dalam trigliserida dalam satuan gram per sajian dan persentase AKG lemak

3. Protein: kandungan semua asam amino dalam produk pangan dicantumkan dalam gram per sajian dan persentase AKG

4. Karbohidrat Total: meliputi gula, pati, serat pangan dan komponen karbohidrat lain dicantumkan dalam gram per sajian dan dalam persentase AKG 5. Natrium: dinyatakan dalam milligram per sajian dan dalam persentase AKG

\section{Zat Gizi yang Wajib Dicantumkan} dengan Persyaratan Tertentu

1. Energi dari Lemak: Energi dari lemak wajib dicantumkan apabila terdapat dalam jumlah yang berarti yaitu lebih dari 0,5 gram lemak namun tidak perlu dicantumkan untuk pangan yang ditujukan bagi anak berusia 6 sampai 24 bulan

2. Lemak Jenuh: wajib dicantumkan apabila terdapat dalam jumlah yang berarti yaitu lebih dari $0,5 \mathrm{~g}$ per sajian dan/atau mencantumkan pernyataan (klaim) tentang lemak, asam lemak, atau kolesterol dan/atau mencantumkan nilai energy dari lemak jenuh. Namun tidak perlu dicantumkan untuk pangan yang ditujukan bagi anak berusia 6 sampai 24 bulan

3. Lemak Trans: wajib dicantumkan apabila terdapat dalam jumlah yang berarti yaitu lebih dari 0,5 gr per sajian dan/atau mencantumkan pernyataan (klaim) tentang lemak, asam lemak atau kolesterol

4. Kolesterol: wajib dicantumkan apabila terdapat dalam jumlah yang berarti yaitu lebih dari $2 \mathrm{mg}$ per sajian dan/atau mencantumkan pernyataan (klaim) tentang lemak, asam lemak atau kolesterol

5. Serat pangan: wajib dicantumkan apabila terdapat dalam jumlah yang berarti yaitu lebih dari 0,5 gram per sajian

6. Gula: wajib dicantumkan apabila terdapat dalam jumlah yang berarti yaitu lebih dari 1 gram per sajian dan/atau mencantumkan pernyataan (klaim) tentang kandungan gula, gula alkohol atau pemanis

7. Vitamin A, C, Zat Besi dan Kalsium: wajib dicantumkan apabila terdapat dalam jumlah yang berarti yaitu lebih dari $2 \%$ AKG per sajian dan/atau pernyataan (klaim) tentang Vitamin A, C, Zat Besi dan Kalsium 
Asep Kusnali, Herti Windya Puspasari, Rustika. Kemitraan Pemerintah-Swasta dalam Industri Pangan untuk Menurunkan Kandungan Gula, Garam dan Lemak dalam Pangan Olahan. DOI:

Berdasarkan Tabel 2, dapat diketahui belum seluruh zat gizi baik gula total, garam total dan lemak total wajib dicantumkan dalam label pangan olahan atau dengan kata lain masih bersifat sukarela. Sehingga untuk melaksanakan Permenkes No. 30 Tahun 2013 perlu dilakukan perubahan terhadap PerKa BPOM No. HK.00.06.51.047.

\section{Pembahasan}

Kebijakan Nasional tentang Kewajiban Pencantuman Informasi Kandungan Gula, Garam dan Lemak Untuk Pangan Olahan

Pencantuman informasi kandungan gula, garam dan lemak dalam Label Pangan berdasarkan Permenkes No. 30 Tahun 2013 merupakan kewajiban bagi setiap orang perseorangan atau korporasi, baik yang berbadan hukum maupun tidak berbadan hukum yang memproduksi pangan olahan yang mengandung Gula, Garam dan/atau Lemak untuk diperdagangkan. Hal ini telah sesuai dengan amanat UU No. 36 Tahun 2009 dimana standardisasi makanan dan minuman yang dikonsumsi masyarakat, memiliki ijin edar, dan penggunaan label bagi makanan kemasan merupakan suatu kewajiban yang harus dilakukan oleh setiap orang memproduksi pangan olahan9. Dampak tidak dipenuhinya kewajiban tersebut yaitu larangan beredar, ditarik dari peredaran, ijin edar dicabut dan disita yang kemudian dimusnahkan. Ketentuan standardisasi bidang makanan dan minuman tersebut telah melahirkan kewajiban pengawasan oleh Badan Pengawas Obat dan Makanan (BPOM) sejak proses produksi, pengolahan, dan pendistribusian makanan dan minuman sedangkan pengawasan dalam rangka pencegahan, pengendalian dan penanganan penyakit tidak menular dilakukan oleh Kementerian Kesehatan dengan Pemerintah Daerah serta dapat melibatkan peran aktif masyarakat.

Kewajiban labelisasi pangan olahan diatur pula dalam UU No. 18 Tahun 2012 tentang Pangan dimana setiap orang yang memproduksi pangan dalam negeri untuk diperdagangkan dan setiap orang yang mengimpor pangan untuk diperdagangkan setelah memasuki wilayah Indonesia wajib mencantumkan label di dalam dan/atau pada kemasan pangan ditulis atau dicetak menggunakan Bahasa Indonesia yang memuat paling sedikit keterangan mengenai a) nama produk; b) daftar bahan yang digunakan; c) berat bersih atau isi bersih; d) nama dan alamat pihak yang memproduksi atau mengimpor; e) halal bagi yang dipersyaratkan; f) tanggal dan kode produksi, tanggal, bulan dan tahun kadaluwarsa; g) nomor izin edar bagi pangan olahan; dan f) asal usul bahan pangan tertentu. Informasi kandungan gula, garam dan lemak dalam makanan dan minuman tidak menjadi syarat minimal dalam UU No. 18 Tahun $2012^{10}$.

Berdasarkan PP No. 69 Tahun 1999 tentang Label dan Iklan Pangan disebutkan bahwa keterangan tentang bahan yang digunakan dalam kegiatan atau proses produksi pangan dicantumkan pada label sebagai bahan secara berurutan dimulai dari bagian yang terbanyak, kecuali vitamin, mineral dan zat penambah gizi lainnya ${ }^{11}$. Berdasarkan Perka BPOM No. HK.00.06.51.0475 tentang Pedoman Pencantuman Informasi Nilai Gizi pada Label Pangan, yang dimaksud zat gizi lain berupa karbohidrat, protein, lemak dan komponen serta turunannya termasuk energi. Hal ini berarti gula, 
garam dan lemak merupakan jenis kandungan gizi lain dalam pangan. Selain itu, sifat wajib label gizi hanya terhadap produk yang mencantumkan klaim, dan dipersyaratkan oleh peraturan perundangan. Sifat wajib pencantuman informasi kandungan gula, garam dan lemak dalam Permenkes No. 30 Tahun 2013 belum sinkron dengan Perka BPOM No. HK.00.06.51.0475 $5^{12}$.

Perbandingan dengan negara lain, Tabel 1 memperlihatkan informasi peraturan pelabelan yang berlaku di beberapa negara yaitu Food Labeling Guide (FDA) yang berlaku di Amerika Serikat, Labeling of Packaged Food yang berlaku di Australia, serta Euro Council 2000/13/EC yang berlaku di Uni Eropa dan merupakan revisi dari Euro Council 79/112/EC. Selain itu, terdapat pula peraturan pelabelan yang dikeluarkan oleh Codex Allimentarius Commission (Codex Stan 11985) (Hikmatiar, 2013; Gunanta, 2007) ${ }^{13}$. Peraturan di Amerika Serikat dan Australia mewajibkan mencantumkan informasi gizi pada label pangan. Jika melihat ketentuan minimal informasi gizi dalam PP No. 69/1999, pencantuman informasi kandungan gula, garam dan lemak bukan merupakan suatu kewajiban, namun 'secara terbatas' kewajiban itu pada pencantuman zat gizi dalam label pangan yang telah diatur dalam Peraturan Kepala BPOM No. HK.00.06.51 ${ }^{12}$. Hal ini berarti belum semua pangan olahan diwajibkan untuk melaksanakan kebijakan dalam Permenkes No. 30 Tahun 2013. Peraturan BPOM tersebut menyebutkan bahwa tidak semua label pangan wajib mencantumkan informasi nilai gizi, kecuali label pangan yang disertai pernyataan bahwa pangan mengandung vitamin, mineral dan/atau zat lainnya yang ditambahkan atau dipersyaratkan berdasarkan ketentuan peraturan perundang-undangan yang berlaku dibidang mutu dan gizi pangan, wajib dicantumkan vitamin, mineral, dan atau zat gizi lainnya. Yang dimaksud dengan zat gizi lainnya yaitu karbohidrat, protein, lemak dan komponen serta turunannya, termasuk energi.

\section{Penawaran Kemitraan oleh Industri Pangan Olahan untuk Melaksanakan Permenkes No. 30 Tahun 2013}

Ekonomi kapitalistik barat, prioritas utama pemegang saham pada perusahaan makanan, sama seperti semua perusahaan pada umumnya, harus memperoleh keuntungan finansial yang sebesar-besarnya. Sebagai contoh pasar makanan di Amerika Serikat menyediakan sekitar 3900 kkal per kapita setiap hari, kira-kira dua kali kebutuhan energi penduduk. Untuk memperluas keuntungan di kondisi tersebut, perusahaan makanan hanya memiliki 2 (dua) pilihan, yaitu meyakinkan pelanggan untuk makan lebih banyak sehingga berkontribusi langsung terhadap obesitas atau secara tidak langsung meningkatkan margin keuntungan, terutama dengan memasarkan produk reformulasi atau mengemas ulang (Ludwig \& Nestle, 2008) ${ }^{13}$. Beberapa penelitian menyebutkan terdapat hubungan konsumsi makanan olahan yang sering terhadap kenaikan berat badan dan meningkatnya risiko penyakit (Pereira, et.al, 2005) ${ }^{14}$. Untuk meningkatkan pendapatan perusahaan, strategi industri makanan biasanya bergantung pada kampanye "makan lebih banyak" yang dirancang untuk mempromosikan porsi yang lebih besar, sering ngemil seperti permen, minuman ringan, makanan ringan, dan makanan cepat saji sebagai makanan sehari-hari. Bahkan saran untuk makan 
Asep Kusnali, Herti Windya Puspasari, Rustika. Kemitraan Pemerintah-Swasta dalam Industri Pangan untuk Menurunkan Kandungan Gula, Garam dan Lemak dalam Pangan Olahan. DOI:

makanan dalam porsi yang lebih kecil, dan menghindari makanan berkalori tinggi, sangat jarang karena dapat merusak model bisnis dari banyak perusahaan makanan dan minuman (Ludwig \& Nestle, 2008) ${ }^{13}$.

Kampanye makan lebih banyak saat ini bergulir dalam iklan televisi. Hasil diskusi dengan beberapa praktisi kesehatan masyarakat dan gizi menyebutkan bahwa tayangan iklan di televisi memang lebih banyak menyampaikan bahwa produk pangan olahannya itu sehat namun masyarakat terbatas pengetahuan sejauh mana pangan yang diiklankan tersebut sehat, bergizi atau tidak bergizi sehingga perlu dikuatkan melalui peraturan yang lebih spesifik. Dengan kondisi demikian Pemerintah harus lebih memperkuat regulasi tidak hanya bertujuan untuk mengedukasi gizi yang baik kepada masyarakat, namun juga berupaya untuk mempromosikan bagaimana pola makan yang baik termasuk membaca label pangan olahan, juga mengatur sampai pada pengadaan distribusi pangan kepada konsumen. Ada empat faktor yang mempengaruhi edukasi kepada masyarakat, yaitu pengalaman, lingkungan, ketersediaan pangan dan kebijakan/peraturan terkait dari mulai dari pengadaan sampai distribusi.

Pihak industri sependapat bahwa pencantuman nilai gizi dalam label merupakan salah satu bentuk edukasi kepada masyarakat, namun memberikan pemahaman kepada masyarakat melalui label pangan akan membutuhkan waktu yang cukup lama. Hal ini menunjukkan bahwa informasi melalui iklan di televisi sebenarnya lebih efektif dibandingkan melalui label pangan. Selanjutnya disebutkan bahwa langkah pertama yang harus dilakukan
Pemerintah yaitu melaksanakan promosi kesehatan masyarakat di sekolah-sekolah atau posyandu maupun posbindu karena itu akan lebih tepat jelas dan tepat sasaran.

Berkaitan dengan pelaksanaan Permenkes No. 30 Tahun 2013 dalam menanggulangi penyakit tidak menular dengan menekan tingkat konsumsi gula, garam dan lemak industri pangan berpendapat bahwa hal tersebut perlu dilakukan kajian terlebih dahulu jenis pangan mana yang bisa diterapkan terlebih dahulu karena selama ini Pemerintah hanya membatasi melalui peraturannya namun tidak ada penjelasan bagaimana implementasi dan standarnya. Karena hal tersebut dapat berdampak pada manajemen industri. Selain itu, Pihak industri memberikan masukan bahwa perlu dilakukan sinkronisasi antara kebijakan Kementerian Kesehatan dengan Kementerian Pertanian terkait ketersediaan pangan di masyarakat karena jika anjuran Pemerintah untuk banyak mengkonsumsi buah namun di sektor pertanian tidak cukup tersedia buahnya atau harga buah tidak terjangkau masyarakat maka itu akan menjadi tidak efektif.

Secara umum, hasil diskusi dengan pihak industri pangan siap melaksanakan kebijakan pencantuman informasi kandungan gula, garam dan lemak pada pangan olahannya. Beberapa masukan pihak industri pangan antara lain bahwa industri pangan perlu dorongan agar dapat berperan aktif memproduksi pangan lebih sehat. Pihak industri pangan menawarkan beberapa strategi seperti yang telah dilaksanakan di beberapa Negara maju seperti peningkatan citra organisasi industri pangan (organizational and corporate image) melalui kerangka kerja sama melalui Kemitraan Pemerintah-Swasta (public- 
private partnership) dalam rangka penurunan gula, garam dan lemak dalam produk pangan olahan yang dilakukan secara bertahap. Diharapkan melalui kemitraan tersebut dapat memicu semakin banyak industri pangan lain untuk terlibat, contohnya dalam Public Health Responsibility Deal yang telah dilakukan di negara Inggris dan Millan Declaration di Swiss (Wyness, Butriss \& Stanner, 2012) ${ }^{15}$.

\section{Public Health Responsibility Deal} merupakan Kemitraan Pemerintah-Swasta (KPS) yang dilakukan melalui perjanjian kerjasama antara korporasi dan sektor publik di Inggris, dimana model kerjasama tersebut saat ini banyak digunakan untuk mengatasi masalah di bidang kesehatan (Buse \& Harmer, 2007) ${ }^{16}$. The Public Health Responsibility Deal diluncurkan oleh Coalition Government of Conservatives and Liberal Democrats di Inggris pada tahun 2010 dibentuk berdasarkan perjanjian yang sifatnya sukarela, yaitu kemitraan antara Pemerintah, korporasi, sektor publik dan organisasi nonPemerintah (LSM) dengan tujuan meningkatkan kesehatan masyarakat di bidang makanan, alkohol, kesehatan kerja dan aktivitas fisik. Strategi ini mudah diimplementasikan dan mendapatkan banyak kemajuan, lebih cepat dalam penyelesaian masalah kesehatan, dan dengan biaya yang lebih rendah daripada membentuk suatu peraturan (UK Department of Health, 2015 ; Durand et.al, 2015) $)^{17,18}$.

Disamping kelebihan penerapan KPS tersebut, pihak industri pangan olahan menjelaskan masih terdapat kelemahankelemahan dalam pelaksanannya, antara lain dapat menimbulkan kekhawatiran beberapa pihak industri tentang tidak seimbangnya isi perjanjian kemitraan, Usaha Kecil dan Menengah (UKM) akan sulit masuk dalam kemitraan tersebut karena kurangnya visibilitas model kerjasama tersebut, perusahaan besar berpeluang untuk dapat bekerjasama karena mampu mempengaruhi lebih banyak populasi. Jika Public Health Responsibility Deal direalisasikan, maka pihak industri pangan akan mempertimbangkan atau memperhitungkan potensi keuntungan dan kerugian atas reputasi yang sudah ada dan untuk masa yang akan datang, namun penyelesaian masalah potensi penurunan penyakit tidak menular masih belum optimal. Sehingga walaupun potensi insentif bagi industri pangan sangat menjanjikan namun tetap harus diperkuat dengan adanya sanksi yang lebih formal untuk mendorong partisipasi semua pihak secara seimbang.

Selanjutnya, Milan Declaration di Swiss diawali sekitar tahun 1999 yang dilakukan satuan tugas khusus Italia dengan cara mengumumkan untuk melakukan tindakan yang wajar terhadap obesitas. Tahun 2015, European Association for the Study of Obesity (EASO) bersama dengan Italian Society of Obesity (ISO) mengeluarkan 'Milan Declaration 2015' pada 9th European Congress on Obesity (ECO) yang menyerukan dukungan, dan tindakan nasional untuk memerangi epidemi obesitas. Dalam hal ini, EASO memutuskan untuk memberikan dukungan kepada pemerintah, sebagai bagian dari misinya untuk memfasilitasi dan terlibat dalam tindakan untuk mengurangi obesitas di Eropa (Fruhbeck, et.al, 2016) ${ }^{19}$. Obesitas merupakan pintu gerbang menuju banyak penyakit lainnya yang dapat melumpuhkan dan mematikan. Tidak hanya mengancam sistem 
Asep Kusnali, Herti Windya Puspasari, Rustika. Kemitraan Pemerintah-Swasta dalam Industri Pangan untuk Menurunkan Kandungan Gula, Garam dan Lemak dalam Pangan Olahan. DOI:

kesehatan global tetapi juga memiliki potensi untuk melumpuhkan ekonomi nasional dan global. Untuk secara efektif memerangi epidemi obesitas, diperlukan pendekatan yang lebih proaktif. Setelah diresmikannya Milan Declaration tindakan prioritas selanjutnya dilakukan penelitian, inovasi, dan fokus pada obesitas, baik sebagai penyakit tidak menular dan pintu gerbang ke diabetes tipe 2 dan penyakit tidak menular serius lainnya (Furhbeck, et.al, 2016) $)^{19}$.

Praktisi Industri Pangan mengemukakan bahwa Milan Declaration telah diikuti oleh 14 (empat belas) perusahaan makanan dan perdagangan ritel untuk mereduksi jumlah gula pada produk yogurt dan breakfast cereals di akhir tahun 2018. Melalui suatu perjanjian, produsen makanan Swiss dan perwakilan perdagangan ritel telah sepakat untuk mengurangi gula tambahan di yogurt sebesar $2,5 \%$ dan menambahkan gula dalam sereal sarapan sebesar 5\% pada akhir tahun 2018. Perjanjian tersebut merupakan bagian dari Milan Declaration, yang ditandatangani pada tahun 2015 dengan tujuan untuk mengurangi gula secara bertahap (Foodbev Media, 2018) ${ }^{20}$.

Pada tahun 2016, Swiss Federal Food Safety and Veterinary Office (FFSVO) melakukan survei awal terkait kandungan gula dalam yogurt dan sereal sarapan. Data menunjukkan bahwa yogurt di Swiss mengandung rata-rata $17 \mathrm{~g}$ gula per pot $(180 \mathrm{~g})$, dan sereal sarapan rata-rata $18 \mathrm{~g}$ gula per $100 \mathrm{~g}$. Dan pada akhir Agustus 2017, hasil survei kandungan gula kedua menunjukkan bahwa kadar gula tambahan rata-rata di yogurt telah turun sejak saat itu sekitar 3\%, dan dalam sereal sarapan sebanyak sekitar 5\%. Data tentang kandungan gula dikumpulkan setiap tahun untuk memverifikasi pengurangan yang dijanjikan sebagai bagian dari Milan Declaration. Kerjasama dengan produsen makanan telah terbukti berhasil, Milan Declaration akan dilanjutkan setelah 2018 sebagai bagian dari rencana aksi untuk strategi gizi di Swiss hingga 2024. Dan selanjutnya akan mulai ditangani pada masalah konsumsi garam dan lemak.

\section{Dukungan Pemerintah dalam Pelaksanaan Permenkes No. 30 Tahun 2013}

Strategi terhadap pencantuman informasi kandungan gula, garam dan lemak pada pangan olahan berikut ini merupakan studi perbandingan untuk mencari alternatif terbaik dalam melaksanakan kebijakan,

a) Reduksi gula melalui Strategi Intervensi Berbasis Masyarakat dan Pengenaan Pajak Impor

Strategi intervensi melalui reduksi gula, pernah dilakukan WHO dengan menggunakan pendekatan community based intervention yaitu pengenaan pajak terhadap pangan yang mengandung gula. Namun, hasil konfirmasi data di Direktorat P2PTM, pendekatan pengenaan pajak terhadap gula diprediksi akan memperoleh permasalahan saat ini kaena kebijakan Kementerian Keuangan saat ini hanya memberikan pembatasan berupa pajak terbatas pada alkohol dan produk tembakau. Sehingga diperlukan perubahan kebijakan jika akan menambahkan zat gula sebagai bahan yang dikenai pajak, dan harus memiliki alasan yang kuat serta ilmiah bahwa mengkonsumsi gula dianggap membahayakan lingkungan. 
Dijelaskan lebih lanjut bahwa pada dasarnya pengenaan pajak gula dapat dilakukan terhadap pangan yang mengandung gula lebih dari $10 \%$ karena saat ini bahaya gula terhadap kesehatan dapat terlihat dari produk-produk minuman yang mengandung gula tinggi yang banyak dikonsumsi oleh anak-anak.

Menurut studi Barrientos, dkk. (2018), seperti halnya intervensi kesehatan masyarakat, dampak pengenaan pajak tidak dapat diketahui sampai dapat diterapkan dan dipelajari, tetapi penelitian sampai saat ini menunjukkan pajak atas minuman manis dapat memiliki efek positif yang kuat untuk mengurangi konsumsi gula. Artinya bahwa, pajak memiliki potensi untuk menghasilkan pendapatan besar bagi Pemerintah dan mencegah obesitas serta dapat mengatasi biaya eksternal lainnya yang dihasilkan dari konsumsi minuman manis, sehingga anggaran yang ada dapat digunakan untuk mendanai program-program terkait kesehatan lainnya ${ }^{21}$.

Studi yang dilakukan oleh Veerman, dkk. (2016), menyimpulkan bahwa pajak atas makanan dan minuman manis memiliki potensi untuk mengurangi beban penyakit yang disebabkan konsumsi makanan dan minuman manis tersebut dan mengurangi biaya perawatan kesehatan yang terkait dalam jangka pendek. Namun, sementara ini pajak pada makanan dan minuman manis tidak ada dalam agenda politik di Australia, untuk itu diperlukan bukti dan pengalaman internasional, sehingga pajak pada makanan dan minuman manis harus dianggap sebagai bagian dari agenda reformasi pajak di Australia $^{22}$.
Berbeda dengan studi Wang dkk. (2016), strategi intervensi berbasis masyarakat menggunakan pendekatan berbasis narasi melalui Narrative Modul sebagai tools yang dijadikan instrumen di kalangan remaja. Pendekatan tersebut melalui penyajian pesan dalam konteks cerita yang dapat memfasilitasi hubungan pesan kesehatan dengan memberdayakan remaja sebagai agen perubahan perilaku dalam keluarga mereka. Contoh pendekatan berbasis narasi berupa pengintegrasian buku komik, novel, dan live peer stories dalam intervensi untuk memperkuat perilaku kesehatan yang ditargetkan. Hasil penelitiannya menunjukkan intervensi tersebut memiliki potensi untuk mengurangi konsumsi minuman manis dan risiko obesitas baik di kalangan remaja maupun keluarganya. Temuan dari studi ini akan digunakan untuk menilai efektivitas dalam mengurangi konsumsi minuman manis di kalangan pemuda dan keluarga di Amerika Serikat.

\section{b) Reduksi garam melalui pendekatan reformulasi pangan}

Salah satu upaya yang dapat dilakukan Pemerintah dalam menurunkan prevalensi penyakit tidak menular yang diakibatkan oleh konsumsi garam adalah melalui reformulasi garam dalam produk pangan. Misalnya mie instan di Indonesia saat ini mengandung kadar garam yang cukup tinggi sehingga perlu dilakukan reformulasi kembali kandungan garamnya. Pendekatan reformulasi dilakukan dengan mempertimbangkan keuntungan kedua belah pihak (win win solution) antara kepentingan industri pangan dengan 
Asep Kusnali, Herti Windya Puspasari, Rustika. Kemitraan Pemerintah-Swasta dalam Industri Pangan untuk Menurunkan Kandungan Gula, Garam dan Lemak dalam Pangan Olahan. DOI:

Pemerintah karena pada akhirnya jika konsumen banyak yang sakit maka produsen akan kehilangan market karena konsumen sakit tidak dapat mengkonsumsi produk hasil produksinya.

Pendekatan reformulasi tersebut masih belum ditentukan apakah akan bersifat voluntary atau mandatory. Sebagai perbandingan pelaksanaan pengurangan garam melalui reformulasi akan diambil contoh di Inggris yang pelaksanaannya bersifat sukarela. Dalam brief kebijakan yang disampaikan Food Standards Agency (Alette, 2010) kepada Departemen Kesehatan di Inggris menyebutkan bahwa pilihan kebijakan reformulasi kandungan garam dalam pangan secara sukarela dapat meningkatkan kesadaran publik menjadi sangat efektif dari segi pembiayaan kesehatan. Diperkirakan bahwa pengurangan $10 \%$ dalam asupan yang dicapai hingga saat ini menghemat ekonomi hingga £1,5 miliar dan mencegah sekitar 6.000 kematian prematur setiap tahun. Hal ini akan jauh berbeda jika kebijakan reformulasi kandungan garam diatur secara preskriptif yang dapat menyebabkan masalah yang kompleks dari keberagaman pangan yang mengandung sodium, intervensi Pemerintah berpotensi tertunda karena peraturan masih disusun dan belum disetujui, dapat menjadi beban yang signifikan pada industri pangan dan membutuhkan biaya penegakan (enforcement) yang cukup mahal. Strategi pengurangan garam telah dilakukan melalui beberapa pendekatan yaitu kampanye kesehatan masyarakat, kolaborasi dengan industri pada reformulasi dan pengembangan skema pelabelan nutrisi front-of-pack tunggal $^{23}$.

Dalam mekanisme reformulasi sukarela ini, pembuat kebijakan harus menyadari bahwa bisnis industri pangan akan menghadapi hambatan yang mungkin saja tidak mereka pertimbangkan. Bahkan dalam bisnis, skema reformulasi secara sukarela dapat menimbulkan biaya yang signifikan. Dengan demikian, harus ada peluang bagi industri pangan untuk mengembangkan keunggulan kompetitif dalam iklim ekonomi saat ini.

Strategi pengurangan garam nasional sekarang diimplementasikan di negara-negara di semua tingkat pendapatan. Strategi pengurangan garam nasional yang diidentifikasi sebelumnya terbatas pada negara dengan pendapatan tinggi (25 negara) dan negara berpendapatan menengah atas (7 negara). Saat ini ada sekitar 41 negara berpenghasilan tinggi, 21 negara berpendapatan menengah atas, 11 negara berpendapatan menengah bawah, dan 1 negara berpenghasilan rendah melakukan strategi pengurangan garam nasional (Trieu, et.al., 2015) $)^{24}$.

Strategi pelaksanaan pengurangan garam diantaranya melalui reformulasi pangan, pendidikan konsumen, pelabelan kemasan, intervensi di institusi lembaga publik (seperti sekolah, rumah sakit dan tempat kerja) dan perpajakan. Hasil studi menunjukkan mayoritas tinggi (81\%) menggunakan strategi pengurangan garam nasional melalui mekanisme reformulasi makanan. Dalam kerangka legislasi, selama 
beberapa dekade, terdapat dua pendorong utama pelaksanaan reformulasi diperdebatkan, yaitu apakah perlu diatur dalam suatu peraturan perundang-undangan atau melalui perjanjian kerjasama secara sukarela dengan pihak industri pangan (Van de Velde, et.al, 2016) ${ }^{25}$.

Dalam hal kebijakan reformulasi pangan diterapkan di Indonesia, maka perlu mempertimbangkan dua pendekatan di atas, apakah akan melalui suatu peraturan perundang-undangan atau melalui mekanisme kerja sama, sehingga perlu dikaji lebih lanjut keefektifan pendekatan yang dapat dilaksanakan di Indonesia. Saat ini Indonesia sedang menggalakkan program Gerakan Masyarakat Hidup Sehat (GERMAS), sehingga salah satu atau bahkan kedua pendekatan tersebut dapat diintegrasikan dengan program tersebut. Secara peraturan perundang-undangan, GERMAS diatur dalam Instruksi Presiden No. 1 Tahun 2017 tentang Gerakan Masyarakat Hidup Sehat yang bersifat preskriptif dan disisi lain, pelaksanaan GERMAS dapat melibatkan seluruh komponen bangsa secara sistematis dan terencana melalui suatu komitmen bersama dalam mencegah dan mengendalikan penyakit tidak menular.

\section{c) Deregulasi Trans-Fat Bans}

Lemak trans adalah sejenis asam lemak tidak jenuh dan dapat diklasifikasikan sebagai alami atau diproduksi secara industri yang diproduksi menggunakan teknik pemrosesan industri (Stender, Astrup \& Dyerberg, 2008) $)^{26}$. Beberapa contoh makanan lemak trans misalnya fast food berupa makanan yang dipanggang seperti pies, cookie, kue kering, dan roti manis, biscuit; makanan yang digoreng misalnya kentang goreng, nugget ayam, kebab. Selain itu terdapat dalam produk-produk yang dijual di supermarket seperti popcorn yang siap-untuk-microwave; serta beberapa kue, wafer, dan roti. Untuk kategori lemak dan minyak yang mengandung lemak trans seperti minyak terhidrogenasi sebagian; beberapa margarin (terutama dari industri). Di Indonesia, khususnya di daerah pedesaan, kontribusi tertinggi konsumsi asam lemak dari olahan gorengan, walaupun masyarakat sudah mulai selektif dalam memilih makanan, namun kelemahan dalam pengolahan makanan menggunakan minyak goreng yang masih banyak menggunakan minyak dengan kemasan tanpa label (Ulfa, Subagio \& Nuryanto, 2017).

Pengaturan pangan tanpa lemak trans merupakan salah satu agenda Badan POM yang telah di atur untuk memeriksa semua komposisi pangan yang terdaftar di Badan POM bebas dari lemak trans walaupun tidak secara tegas dilarang seperti yang telah dilakukan dalam Food and Drug Administration (FDA) Amerika Serikat (Detikfood.com, 2013) ${ }^{27}$. Peraturan pembatasan penggunaan lemak trans berhasil diterapkan di beberapa negara bagian seperti di California. Selain itu, FDA Amerika Serikat telah mengeluarkan Federal Register Notice yang umumnya dianggap aman (generally regarded as safe/GRAS). Keberhasilan penerapan kebijakan tersebut menunjukkan bahwa pengurangan lemak 
Asep Kusnali, Herti Windya Puspasari, Rustika. Kemitraan Pemerintah-Swasta dalam Industri Pangan untuk Menurunkan Kandungan Gula, Garam dan Lemak dalam Pangan Olahan. DOI:

trans dimungkinkan melalui batas-batas yang diatur dalam suatu regulasi.

Pelarangan penggunaan lemak trans di Indonesia dapat dilihat dalam Perka BPOM No. 21 Tahun 2016 tentang Kategori Pangan. Pangan dengan kategori lemak dan minyak nabati seperti minyak goreng (frying oil) harus memiliki karakteristik dasar dengan kadar asam lemak trans $0 \%$ dari total asam lemak, demikian sama halnya dengan minyak goreng padat (frying fat $)^{28}$. Namun dalam Perka BPOM No. 13 Tahun 2016 tentang Klaim pada Label dan Iklan Pangan Olahan masih belum secara tegas melarang penggunaan lemak trans dalam klaim pangan olahan. Dalam peraturan tersebut disebutkan bahwa klaim pangan olahan yang mengandung lemak jenuh dan kolesterol "rendah" dan "bebas" harus memenuhi syarat rendah lemak trans. Namun untuk pangan olahan yang mengandung lemak trans harus memenuhi syarat rendah lemak jenuh ${ }^{29}$. Demikian pula dalam Perka BPOM Nomor HK.03.1.23.11.11.09657 Tahun 2011 tentang Persyaratan Penambahan Zat Gizi dan Zat Non Gizi dalam Pangan Olahan, yang masih memberikan batasan dalam sediaan minyak DHA yang berasal dari minyak ikan (maksimal 2\%), sediaan serbuk DHA yang berasal dari minyak ikan (maksimal 1\%), sediaan minyak DHA yang berasal dari minyak sel tunggal (maksimal $2 \%$ dari asam lemak total), dan sediaan minyak ARA yang berasal dari minyak sel tunggal (maksimal 2\% dari asam lemak total).

Terdapat 2 (dua) argumen utama mengapa lemak trans dilarang (Resnik, 2010).
Argumen pertama, larangan lemak trans dibenarkan untuk mempromosikan kesehatan masyarakat. Larangan lemak trans dapat meningkatkan kesehatan masyarakat dengan mengurangi konsumsi lemak trans, yang dapat mengurangi insiden dan keparahan penyakit kardiovaskular. Dalam contoh di Amerika Serikat di atas, menghilangkan lemak trans secara total dari pasokan makanan telah menyelamatkan 50.000 jiwa per tahun. Sistem keamanan pangan dan regulasi yang berkualitas telah membantu mencegah industri pangan untuk merugikan masyarakat melalui produk pangan yang tidak sehat, tetapi juga mereka diarahkan untuk dapat membantu konsumen dalam membuat pilihan pangan yang sehat ${ }^{30}$.

Argumen kedua untuk larangan trans fat adalah faktor ekonomi. Larangan lemak trans buatan dapat berpotensi menghemat miliaran dolar dalam perawatan kesehatan dan biaya terkait dengan mengurangi prevalensi dan keparahan penyakit kardiovaskular. Di Amerika Serikat, lebih dari 80 juta orang (36\% dari populasi) memiliki penyakit kardiovaskular (biaya langsung dan tidak langsung penyakit kardiovaskular berjumlah sekitar \$ 305 miliar) di Amerika Serikat pada tahun 2009. Jika larangan nasional untuk lemak trans buatan mengurangi biaya penyakit kardiovaskular hanya $10 \%$, ini akan menghemat \$30 miliar per tahun (Resnik, 2010 $)^{30}$.

Langkah Indonesia dalam membatasi penggunaan lemak trans harus memperhatikan beberapa opsi kebijakan termasuk batasan legislatif pada kandungan 
lemak trans, pengurangan sukarela oleh pelaku industri pangan dan penggunaan trans fat, dan pelabelan trans fat yang bersifat wajib. Menetapkan batas penggunaan lemak trans secara hukum dalam semua produk pangan kemungkinan adalah pilihan yang paling efektif untuk mengurangi jumlah masyarakat yang yang mengkonsumsi lemak trans buatan sehingga berpotensi mengurangi risiko penyakit. Pemberian label wajib dan reformulasi secara sukarela dimungkinkan akan menghadapi hambatan khususnya pada produk pangan yang tidak dikemas dan pangan yang diproduksi usaha kecil dan menengah mungkin terus mengandung lemak trans.

\section{Kesimpulan}

Kebijakan pencantuman informasi kandungan gula, garam dan lemak serta pesan kesehatan untuk pangan olahan perlu disertai dengan perubahan Pedoman Pencantuman Informasi Nilai Gizi pada Label Pangan. Pada dasarnya industri pangan di Indonesia dapat melaksanakan kebijakan pencantuman informasi kandungan gula, garam dan lemak serta pesan kesehatan untuk pangan olahan, namun untuk melaksanakan kebijakan tersebut, industri pangan menawarkan model kemitraan pemerintah-swasta yaitu Public Health Responsibility Deal seperti yang telah dilakukan di negara Inggris dan Millan Declaration di Swiss. Tujuannya yaitu untuk meningkatkan citra organisasi dimana industri pangan dapat ikut berperan aktif dalam upaya menurunkan asupan gula, garam dan lemak pada produk pangan yang dilakukan secara bertahap. Hal ini dapat juga mendukung Pemerintah dalam upaya penurunan kandungan gula garam dan lemak baik yang dilakukan secara sukarela maupun represif melalui regulasi yang berkualitas.

Alternatif kebijakan yang dilakukan Pemerintah antara lain, Pertama mempersiapkan petunjuk teknis pelaksanaan kebijakan pencantuman informasi kandungan gula, garam dan lemak serta pesan kesehatan dalam pangan olahan serta merevisi kebijakan pencantuman informasi nilai gizi pada label pangan. Kedua, melakukan reduksi gula melalui strategi berbasis masyarakat melalui pengenaan pajak terhadap pangan yang mengandung gula dan pajak impor gula. Ketiga, melakukan reduksi garam melalui pendekatan reformulasi pangan dengan mempertimbangkan keuntungan antara pihak industri pangan dengan Pemerintah. Keempat, mengakomodasi pembatasan penggunaan transfat melalui deregulasi.

\section{Ucapan Terima Kasih}

Ucapan terima kasih kami sampaikan kepada seluruh tim dan narasumber yang tidak dapat disebutkan satu per satu dalam Kajian Terhadap Kebijakan Pencantuman Informasi Kandungan Gula, Garam dan Lemak Serta Pesan Kesehatan untuk Pangan Olahan dan Pangan Siap Saji yang telah dilaksanakan tahun 2017.

\section{Daftar Pustaka}

1. Rahajeng, E. \& Tuminah, S. Prevalensi Hipertensi dan Determinannya di Indonesia, Majalah Kedokteran Indonesia. 2009; 59 (12).

2. Handajani A, Roosihermiatie B \& Maryani H. Faktor-Faktor yang Berhubungan dengan Pola Kematian pada Penyakit Degeneratif di 
Asep Kusnali, Herti Windya Puspasari, Rustika. Kemitraan Pemerintah-Swasta dalam Industri Pangan untuk Menurunkan Kandungan Gula, Garam dan Lemak dalam Pangan Olahan. DOI:

Indonesia, Buletin Penelitian Sistem Kesehatan. 2010;13 (1): 42-53.

3. World Health Organization. Noncommunicable diseases country profiles 2014. 2014.

Availablefromhttp://apps.who.int/iris/bitstr eam/10665/128038/1/9789241507509_eng. pdf?ua $=1$

4. Badan Penelitian dan Pengembangan Kesehatan. Riset Kesehatan Dasar (Riskesdas) Tahun 2013. Badan Penelitian dan Pengembangan Kesehatan; 2013

5. Akari, S., Mateti, U. V., \& Kunduru, B. R. Health-care cost of diabetes in South India: A cost of illness study, Journal of research in pharmacy practice. 2013; 2(3), 114-7.

6. Kementerian Kesehatan Republik Indonesia. Peraturan Menteri Kesehatan Nomor 30 Tahun 2013 tentang Pencantuman Informasi Kandungan Gula, Garam, dan Lemak serta Pesan Kesehatan untuk Pangan Olahan dan Pangan Siap Saji. Jakarta: Berita Negara: 2013 (617).

7. Badan Standardisasi Nasional. Sidang Komite WTO TBT adalah forum perjuangan hambatan perdagangan antar negara anggota WTO. 2014.

Available from http://www.bsn.go.id/main/berita/berita_det 15137/Sidang-Komite-WTO-TBT-adalahforum-perjuangan-hambatan-perdaganganantar--negara-anggotaWTO\#.Wbo608gjHIU

8. Kementerian Kesehatan Republik Indonesia. Peraturan Menteri Kesehatan Nomor 63 Tahun 2015 tentang Perubahan Peraturan Menteri Kesehatan Nomor 30 Tahun 2013 tentang Pencantuman Informasi Kandungan Gula, Garam, dan Lemak serta Pesan Kesehatan untuk Pangan Olahan dan Pangan Siap Saji. Berita Negara: 2015 (1402)

9. Undang-Undang Republik Indonesia Nomor 36 Tahun 2009 tentang Kesehatan. Lembaran Negara: 2009. (144 \& 5063)

10. Undang-Undang Rpublik Indoneisia Nomor 18 Tahun 2012 tentang Pangan. Lembaran Negara: 2012 (227\&5360)
11. Peraturan Pemerintah Republik Indonesia Nomor 69 Tahun 1999 tentang Label dan Iklan Pangan. Lembaran Negara: 1999 (131\&3867)

12. Badan Pengawasan Obat dan Makanan Republik Indonesia. Peraturan Kepala Badan Pengawas Obat dan Makanan Nomor HK.03.1.23.11.11.09605 Tahun 2011 tentang Pedoman Pencantuman Informasi Nilai Gizi pada Label Pangan. 2011

13. Ludwig DS, Nestle M. Can the Food Industry Play a Constructive Role in the Obesity Epidemic. JAMA. 2009: 300(15): 1808-1811. doi:10.1001/jama.300.15.1808

14. Pereira MA, Kartashov AI, Ebbeling CB, Van Horn L, Slattery ML, Jacobs DR Jr, Ludwig DS. Fast food habits, weight gain, and insulin resistance (the CARDIA study): 15-year prospective analysis. Lancet (London, England), 2005: 365 (9453):36-42

15. Gunanta P. Mempelajari Pemenuhan Syarat Label dari Beras Berlabel di Beberapa Swalayan di Jakarta. Skripsi. Bogor: Institut Pertanian Bogor, 2007.

16. Wyness, L., Butriss, J., \& Stanner, S. Reducing the population's sodium intake: The UK Food Standards Agency's salt reduction programme. Public Health Nutrition, 2012:15(2),254-261. doi:10.1017/S1368980011000966

17. Buse, K. \& Harmer, A.M. Seven habits of highly effective global public-private health partnerships: practice and potential. Social Science and Medicine, 1982: 64 (2): 259-71

18. UK Department of Health. The Public Health Responsibility Deal 2015. Available from https://responsibilitydeal.dh.gov.uk/

19. Durand, M. A., Petticrew, M., Goulding, L., Eastmure, E., Knai, C., \& Mays, N. An evaluation of the Public Health Responsibility Deal: Informants experiences and views of the development, implementation and achievements of a pledge-based, public-private partnership to improve population health in England. Health Policy, 2015;119(11):1506-14. doi: 10.1016/j.healthpol.2015.08.013. 
20. Frühbeck G, Sbraccia P, Nisoli E, Woodward E, Yumuk V, Farpour-Lambert N, J, Halford J, G, C, Toplak H, Carruba M, O. Milan Declaration: A Call to Action on Obesity - an EASO Position Statement on the Occasion of the 2015 EXPO. Obesity Facts, 2016(9):296-298. doi: $10.1159 / 000448234$

21. Foodbev Media. "Danone and Kellog's sign up to Swiss Sudar Reduction Scheme". 2017. Available from https://www.foodbev.com/news/danonekelloggs-sign-swiss-sugar-reductionprogramme/

22. Barrientos-Gutierrez T, Zepeda-Tello R, Rodrigues ER, Colchero MA, RojasMartínez R, et al. Correction: Expected population weight and diabetes impact of the 1-peso-per-litre tax to sugar sweetened beverages in Mexico. Plos One, 201813(1): e0191383.

https://doi.org/10.1371/journal.pone.01913 $\underline{83}$

23. Veerman, JL., Sacks, G., Antonopoulos, N., Martin, J. The Impact of a Tax on Sugar Sweetened Beverages on Health and Health Care Costs: A Modelling Study. Plosone, 2016;11(4):e0151460.

doi:10.1371/journal.pone.0151460

24. Addison, Alette. Voluntary - Salt Reduction Strategy Reformulation Targets. 2010. Available from https://www.gov.uk/government/uploads/sy stem/uploads/attachment_data/file/31639/1 0-1283-voluntary-salt-reduction.pdf

25. Trieu K, Neal B, Hawkes C, Dunford E, Campbell N, Rodriguez-Fernandez R, et al. Salt Reduction Initiatives around the World - A Systematic Review of Progress towards the Global Target. Plosone, 2015. 10(7): e0130247.

https://doi.org/10.1371/journal.pone.01302 $\underline{47}$

26. Van de Velde, F.; Van Gunst, A.; Roodenburg, A.J.C. Framework for product reformulation: The integration of four disciplines: Nutrition \& health, food technology, legislation and consumer perspective. New Food, 2016; 19, 27-31

27. Stender, S., Astrup, A., \& Dyerberg, J. Ruminant and industrially produced trans fatty acids: health aspects. Food \& nutritionresearch, 2008;52.10.3402/fnr.v52i 0.1651 .

28. Detikfood. "FDA Larang Pemakaian Lemak Trans dalam Makanan". 2013. Available from https://food.detik.com/info-sehat/d2411375/fda-larang-pemakaian-lemaktrans-dalam-makanan

29. Badan Pengawasan Obat dan Makanan Republik Indonesia. Peraturan Kepala Badan Pengawas Obat dan Makanan Nomor 21 Tahun 2016 tentang Pendaftaran Pangan Olahan.

30. Badan Pengawasan Obat dan Makanan Republik Indonesia. Peraturan Kepala Badan Pengawas Obat dan Makanan Nomor 13 Tahun 2016 tentang Pengawasan Klaim pada Label dan Iklan Pangan Olahan.

31. Resnik D. Trans fat bans and human freedom. The American journal of bioethics: $A J O B, 2010 ; 10(3): 27-32$. Available from https://www.ncbi.nlm.nih.gov/pmc/articles/ PMC3941190/pdf/ nihms-561150.pdf 